\title{
PENINGKATAN KEMAMPUAN PENALARAN DAN KEMANDIRIAN BELAJAR MATEMATIK MELALUI PENDIDIKAN MATEMATIKA REALISTIK INDONESIA (PMRI) UNTUK SISWA SMP
}

\author{
Dwi Sulistya Kusumaningrum \\ dwisulistya1989@gmail.com \\ Universitas Buana Perjuangan Karawang
}

\begin{abstract}
Abstrak
Kemampuan penalaran matematik merupakan bagian dari tujuan kurikulum bagi siswa sekolah dasar sampai menengah. Lebih lanjut kemandirian belajar matematik sendiri merupakan salah satu aspek afektif yang mendukung tercapainya pproses dan hasil pembelajaran yang baik dan di inginkan. Penelitian ini bertujuan menelaah peningkatan kemampuan penalaran dan kemandirian belajar matematik siswa yang memperoleh pembelajaran matematika dengan pendekatan PMRI dibandingkan dengan siswa yang memperoleh pembelajaran dengan pendekatan konvensional. Desain penelitian ini adalah kuasi eksperimen dengan kelompok pretest dan posttest. Kelompok eksperimen memperoleh pembelajaran dengan pendekatan PMRI dan kelompok kontrol memperoleh pembelajaran dengan pendekatan konvensional. Metode yang akan digunakan dalam penelitian ini adalah metode eksperimen semu (quasi eksperimental). Populasi penelitian ini adalah seluruh siswa SMPN di Kabupaten Karawang dengan sampel penelitian adalah siswa kelas VII sebanyak dua kelas dipilih secara purposif dari lima kelas yang ada. Isntrumen penelitian ini berupa soal tes kemampuan penalaran matematik dan soal non tes berupa skala kemandirian belajar matematik siswa. Adapun analisis data menggunakan uji parametrik (uji t atau uji t') dan uji non-parametrik Mann Whitney. Hasil pengolahan data menunjukan bahwa (1) Pencapaian kemampuan penalaran matematik siswa SMP yang memperoleh pembelajaran dengan pendekatan PMRI lebih baik daripada siswa yang memperoleh pembelajaran secara konvensional. (2) Peningkatan kemampuan penalaran matematik yang menggunakan pendekatan PMRI tergolong tinggi, sedangkan yang menggunakan pembelajaran konvensional tergolong sedang. (3) Kemandirian belajar matematik siswa SMP yang memperoleh pembelajaran melalui pendekatan PMRI lebih baik daripada siswa yang memperoleh pembelajaran secara konvensional. Maka, pembelajaran dengan pendekatan PMRI dapat menjadi alternatif model pendekatan pembelajaran yang dapat digunakan di Sekolah Menengah Pertama.
\end{abstract}

Kata kunci: Pendekatan Pendidikan Matematika Realistik Indonesia (PMRI), kemampuan penalaran matematik, kemandirian belajar matematik

\section{PENDAHULUAN}

Matematika merupakan salah satu mata pelajaran yang diajarkan pada pendidikan dasar dan pendidikan menengah. Noyes (Wijaya, 2012:5) mengemukakan bahwa dalam pembelajaran matematika dikelas, siswa cenderung dilatih untuk melakukan perhitungan matematika daripada dididik untuk berpikir matematik. Lebih lanjut, Sumarmo (2013:74) menyatakan bahwa kemampuan berpikir matematik siswa perlu dikembangkan dalam pembelajaran matematika. Hal ini menyiratkan bahwa tujuan dari pembelajaran matematik yaitu siswa memiliki kemampuan berpikir matematik menjadi terabaikan. 
Pengembangan kemampuan berpikir matematik tersebut dipengaruhi oleh pendekatan yang digunakan. Menurut Adams et.al. (Wijaya, 2012:5) cara pendekatan dalam pembelajaran matematika sangat dipengaruhi oleh pandangan guru terhadap matematika dan siswa dalam pembelajaran. Dalam setiap pembelajaran matematika guru hendaknya memperhatikan materi prasyarat yang diperlukan, serta dalam setiap kesempatan pembelajaran matematika hendaknya dimulai dengan pengenalan masalahmasalah yang sesuai dengan situasi kehidupan nyata. Selain dipengaruhi oleh pandangan guru tentang posisi dan peran matematika, arah pembelajaran matematika juga dipengaruhi oleh tujuan pendidikan matematika. Dalam proses mengajar matematika, hal terpenting adalah pencapaian pada tujuan pembelajaran yaitu agar siswa mampu memahami sesuatu berdasarkan pengalaman belajarnya.

Kemampuan penalaran matematik merupakan salah satu aspek yang sangat penting dalam pembelajaran matematika. Hal ini sejalan dengan Depdiknas (Shadiq, 2004) yang menyatakan bahwa materi matematika dan penalaran matematik merupakan dua hal yang tidak dapat dipisahkan, yaitu materi matematika dipahami melalui penalaran, dan penalaran dipahami dan dilatih melalui belajar materi matematika. Dengan demikian, dalam berbagai aktivitas pembelajaran matematika, peserta didik semestinya dikondisikan agar selalu menggunakan penalaran yang bersifat logis, kritis, sistematis, tepat, jelas, cermat dan akurat. Jika kemampuan bernalar tidak dikembangkan maka matematika bagi siswa hanya akan dianggap sekedar ilmu hitung. Kemampuan bernalar tidak hanya dibutuhkan dalam proses pembelajaran saja tetapi juga dibutuhkan pada saat memecahkan masalah yang akan berpengaruh terhadap kematangan berpikir seseorang dalam membuat keputusan-keputusan secara logis dalam kehidupannya sehari-hari.

Selain aspek kognitif, aspek afektif juga penting dalam pelajaran matematika. Salah satu kemampuan tersebut adalah kemandirian belajar matematik. Wardani (Tandililing, 2011), menyatakan bahwa aspek afektif juga menentukan keberhasilan siswa dalam belajar matematika, aspek afektif tersebut adalah kemandirian belajar (selfregulated learning). Hal tersebut sejalan dengan Peraturan Menteri Pendidikan dan Kebudayaan Republik Indonesia Nomor 65 Tahun 2013 Tentang Standar Proses Pendidikan Dasar dan Menengah, yakni proses pembelajaran pada satuan pendidikan diselenggarakan secara interaktif, inspiratif, menyenangkan, menantang, memotivasi peserta didik untuk berpartisipasi aktif, serta memberikan ruang yang cukup bagi prakarsa, kreativitas, dan kemandirian sesuai dengan bakat, minat, dan perkembangan fisik serta psikologis peserta didik.

Kegiatan pembelajaran yang diperkirakan dapat diterapkan untuk mengembangkan kemampuan penalaran dan kemandirian belajar matematik siswa salah satunya dengan menggunakan Pendekatan Pendidikan Matematika Realistik Indonesia (PMRI). Menurut pandangan Freudental (Wijaya, 2012:20) matematika harus dihubungkan dengan kenyataan, dekat dengan siswa dan relevan dengan kehidupan nyata sehari-hari siswa. Maka, prinsip utama dalam PMRI adalah "matematika sebagai aktivitas manusia". Penggunaan pendekatan matematika realistik dapat menciptakan lingkungan belajar yang kondusif agar siswa diberikan kesempatan untuk mengkonstruksi kemampuan berpikir dan pemahamannya sendiri. Hal ini sejalan dengan Sumarmo (2013:74) menyatakan bahwa matematika memiliki beberapa karakteristik, antara lain: mathematics as a human activity; proses yang aktif, dinamik dan generatif; ilmu bantu yang memiliki bahasa simbol dan kemampuan analisis kuantitatif; ilmu yang terstruktur dan deduktif yang memuat proses induktif. Maka kegiatan pembelajaran yang 
diperkirakan dapat diterapkan untuk mengembangkan kemampuan penalaran dan kemandirian belajar matematik siswa adalah dengan menggunakan Pendekatan PMRI.

Berdasarkan uraian, maka rumusan masalah dalam penelitian ini antara lain: (1) Apakah pencapaian kemampuan penalaran matematik siswa yang memperoleh pembelajaran dengan pendekatan PMRI lebih baik dari pada kemampuan siswa yang memperoleh pembelajaran secara konvensional? (2) Apakah peningkatan kemampuan penalaran matematik siswa yang memperoleh pembelajaran dengan pendekatan PMRI lebih baik dari pada kemampuan siswa yang memperoleh pembelajaran secara konvensional? (3) Apakah kemandirian belajar matematik siswa yang memperoleh pembelajaran dengan pendekatan PMRI lebih baik dari pada siswa yang memperoleh pembelajaran secara konvensinal?

Sesuai dengan rumusan masalah, maka tujuan penelitian ini adalah sebagai berikut: (1) Menelaah pencapaian kemampuan penalaran matematik siswa yang memperoleh pembelajaran dengan pendekatan PMRI dibandingkan dengan siswa yang memperoleh pembelajaran secara konvensional. (2) Menelaah peningkatan kemampuan penalaran matematik siswa yang memperoleh pembelajaran dengan pendekatan PMRI dibandingkan dengan siswa yang memperoleh pembelajaran secara konvensional. (3) Menelaah kemandirian belajar matematik siswa yang memperoleh pembelajaran dengan pendekatan PMRI dibandingkan dengan siswa yang memperoleh pembelajaran secara konvensional.

Hipotesis dalam penelitian ini yaitu (1) Pencapaian dan peningkatan kemampuan penalaran matematik siswa SMP yang memperoleh pembelajaran melalui pendekatan PMRI lebih baik daripada siswa yang memperoleh pembelajaran konvensional. (2) Kemandirian belajar siswa SMP yang memperoleh pembelajaran melalui pendekatan PMRI lebih baik daripada siswa yang memperoleh pembelajaran konvensional.

\section{TINJAUAN PUSTAKA}

\section{A. Kemampuan Penalaran Matematik}

Penalaran Matematik menurut Nunes, et.al (2009:3) adalah pembelajaran untuk bernalar tentang hubungan mendasar dalam masalah-masalah matematik yang harus mereka selesaikan. Selain itu menurut Bezold et.al (2013:2) menyatakan bahwa penalaran berarti mempertanyakan pernyataan matematik dan membuktikan kebenaran mereka, mengenal hubungan matematik dan mengembangkan asumsi-asumsi; serta mencari dan memahami penalaran. Kemudian, Shurter et.al (Sumarmo, 2013: 448) mendefinisikan penalaran sebagai proses memperoleh kesimpulan logis berdasarkan data dan sumber yang relevan. Sementara berpikir logis memuat kegiatan berpikir logis dan kegiatan matematika lainnya, yaitu: pemahaman, koneksi, komunikasi, dan penyelesaian masalah secara logis. Dengan demikian berpikir logis mempunyai cakupan lebih luas dari penalaran logis.

Sumarmo (2013: 450) menyatakan bahwa penalaran matematik dapat diklasifikafikasikan menjadi dua jenis, yaitu penalaran induktif dan penalarna deduktif. Penalaran induktif adalah penarikan kesimpulan yang bersifat umum atau khusus berdasarkan data yang teramati. Nilai kebenaran dalam penalaran induktif dapat bersifat benar atau salah. Sumarmo (2013: 450) membagi beberapa kegiatan yang tergolong pada penalaran induktif di antaranya adalah: 
a. Penalaran transduktif yaitu proses penarikan kesimpulan dari pengamatan terbatas yang diberlakukan terhadap kasus tertentu.

b. Penalaran analogi yaitu penarikan kesimpulan berdasarkan keserupaan data atau proses.

c. Penalaran generalisasi yaitu penarikan kesimpulan secara umum berdasarkan data yang terbatas.

d. Memperkirakan jawaban, solusi atau kecenderungan: interpolasi dan ekstrapolasi.

e. Memberi penjelasan terhadap model, fakta, sifat, hubungan, atau pola yang ada.

f. Menggunakan pola hubungan untuk menganalisis situasi, dan menyusun konjektur.

Penalaran deduktif yaitu pernalaran yang mengambil kesimpulan berdasarkan hal yang umum, yang telah dibuktikan terlebih dahulu. Menurut Suherman (2003), matematika dikenal sebagai ilmu deduktif. Ini berarti proses pengerjaan matematik harus bersifat deduktif. Salah satu jenis penalaran deduktif adalah penalaran kondisional. Masalah penalaran kondisional (penalaran proposisional) menginformasikan kepada kita mengenai keterkaitan antara dua kondisi. Sumarmo (2013:450) menggolongkan beberapa kegiatan yang termasuk penalaran deduktif di antaranya adalah:

a. Melaksanakan perhitungan berdasarkan aturan atau rumus tertentu.

b. Menarik kesimpulan logis berdasarkan aturan inferensi atau penalaran logis, memeriksa validitas argumen, dan menyusun argumen yang valid

c. Menyusun pembuktian langsung, pembuktian tak langsung dan pembuktian dengan induksi matematika.

Indikator penalaran matematik siswa SMP yang digunakan dalam penelitian ini antara lain: (1) Penarikan kesimpulan berdasarkan keserupaan data atau proses (analogi), (2) Memperkirakan jawaban, solusi atau kecenderungan, (3) Melaksanakan perhitungan matematika berdasarkan aturan atau rumus tertentu yang disepakati, (4) Menarik kesimpulan logis (penalaran proposional).

\section{B. Kemandirian Belajar Matematik}

Pintrich dan Zimmerman (Marchis \& Balogh, 2010) menyatakan bahwa kemandirian belajar (self-regulated learning) adalah 'bentuk kemampuan apektif dari pembelajaran, yang mana pebelajar menyeting tujuan-tujuan dan membuat rencanarencana sebelum memulai belajar; memantau dan mengatur kesadaran, motivasi, dan tingkah lakunya selama proses pembelajaran; dan merefleksikan proses pembelajarannya'. Sejalan dengan hal tersebut, Zimmerman (Darr \& Fisher, 2004:1) menyatakan bahwa teori kemandirian belajar terkait dengan siswa-siswa yang menjadi pengendali (masters) pada proses

Sumarmo (2013) merumuskan indikator kemandirian belajar sebagai berikut: (1) Berinisiatif belajar matematika dengan atau tanpa bantuan orang lain; (2) Merumuskan/memilih/ membuat target belajar; (3) memilih dan menggunakan berbagai sumber belajar; (4) memilih strategi dan mengevaluasi hasil belajarnya; (5) bekerjasama dengan orang lain; (6) membangun makna; (7) mengontrol diri; (8) memiliki kepercayaan diri; (9) berperilaku disiplin; (10) memiliki rasa tanggung jawab. 


\section{Pendekatan Pendidikan Matematika Realistik Indonesia(PMRI)}

PMRI adalah suatu pendekatan pembelajaran matematika yang menggunakan konteks. Konteks tersebut tidak hanya berasal dari dunia nyata, tetapi dapat dari dunia fantasi atau cerita rekaan dan dunia formal dari matematika, asalkan hal tersebut nyata dalam pikiran siswa. Panhuizen (Wijaya, 2012:20-21) menyatakan penggunaan kata "realistik" berasal dari bahasa Belanda "zich realiseren" yang berarti "untuk dibayangkan" atau "to imagine". Penggunaan kata "realistik" tersebut tidak sekedar menunjukan adanya suatu koneksi dengan dunia nyata (real-world) tetapi lebih mengacu pada fokus pendidikan matematika realistik dalam menempatkan penekanan penggunaan suatu situasi yang bisa dibayangkan (imagineable) oleh siswa.

Terdapat lima karakteristik dari Realistic Mathematics Education yang dijadikan acuan dalam penerapan pembelajaran matematika di kelas. Kelima karakteristik tersebut digagas oleh Treffers tahun 1987 (Bakker, 2004: 6) yaitu: (1) The use of contextual problems (Penggunaan konteks); (2) Using models and symbols for progressive mathematization (Penggunaan berbagai model dan simbol untuk matematisasi progesif); (3) Using students' own constructions and productions (Penggunaan hasil kontruksi dan produksi siswa); (4) Interactivity (Interaktivitas); (5) Intertwinment (Keterkaitan).

Roth (Wijaya 2012: 32) menjelaskan bahwa penggunaan konteks untuk menggambarkan situasi atau deskripsi situasi dari suatu masalah. Melalui penggunaan konteks, siswa dilibatkan secara aktif untuk melakukan kegiatan eksplorasi permasalahan. Konteks dalam PMRI ditujukan untuk membangun atau menemukan kembali suatu konsep matematika melalui proses matematisasi. Secara sederhana proses matematisasi adalah proses menerjemahkan suatu konteks menjadi konsep matematika. De Lange (Wijaya 2012: 42-43) membagi matematisasi menjadi dua, yaitu matematisasi horizontal dan matematisasi vertikal. Proses matematisasi horizontal dapat dicapai melalui kegiatan: a) identifikasi matematika dalam suatu konteks umum; b) skematisasi; c) formulasi dan visualisasi masalah dalam berbagai cara; d) pencarian keteraturan dan hubungan; e) transfer masalah nyata kedalam model matematika. Proses matematisasi vertikal melalui kegiatan sebagai berikut: a) representasi suatu relasi kedalam suatu rumus atau aturan; b) pembuktian keteraturan; c) penyesuaian dan pengembangan model matematika; d) penggunaan model matematika yang bervariasi; e) pengombinasian dan pengintegrasian model matematika; f) perumusan suatu konsep matematika baru; g) generalisasi.

Pada penggunaan hasil kontruksi dan produksi, siswa sebagai subjek belajar bebas mengembangkan ide atau strategi dalam penyelesaian masalah. Pada prosesnya diharapkan adanya variasi penyelesaian masalah sehingga dapat mengembangkan aktivitas dan kreativitas siswa. Hasil konstruksi siswa selanjutnya digunakan sebagai landasan pengembangan konsep matematika.

Proses pembelajaran dikelas tidak hanya proses individu tetapi bersamaan dengan proses sosial. Proses pembelajaran akan bermakna ketika siswa saling mengkomunikasikan ide, model, hasil gagasan, dan penalaran mereka. Lebih lanjut, interaktivitas dapat mengajarkan nilai-nilai untuk mengembangkan kemampuan afektif siswa. Konsep-konsep dalam matematika tidak bersifat parsial, tetapi banyak konsep matematika yang memiliki keterkaitan. Pengenalan konsep matematika kepada siswa tidak diajarkan secara terpisah. PMRI menempatkan keterkaitan antar konsep 
matematika agar siswa dapat mengenal dan membangun lebih dari satu konsep matematika secara bersamaan (walau ada konsep yang dominan).

Prinsip PMRI pada praktek pembelajaran matematika di kelas seringkali diabaikan. Noornia (2008) menyatakan bahwa kondisi saat ini dimulai dari tingkat Sekolah Dasar hingga Sekolah Menengah Atas, terjadi yang disebut dengan iceberg phenomenon atau fenomena gunung es. Puncak gunung es biasanya mengapung di laut dan terlihat kecil dari atas permukaan laut, padahal bagian dasar dari gunung es yang lebih besar berada di bawah permukaan air laut. Matematika formal yang telah tersaji dalam bentuk angka dan rumus adalah puncak dari gunung es atau top of iceberg dari konsep matematika. Sedangkan konsep matematika yang sebenarnya lebih luas dan besar berada pada dasar gunung es di bawah permukaan air laut. Maka matematika hanya dipandang sebagai kumpulan angka dan rumus, yang dikhawatirkan siswa tidak dapat mengaplikasikan matematika dalam kehidupannya.

\section{METODE PENELITIAN}

Metode yang digunakan dalam penelitian ini adalah metode eksperimen semu (quasi eksperimental) dengan perlakuan yang diberikan adalah pendekatan PMRI, dan variabel yang diukurnya adalah kemampuan penalaran dan kemandirian belajar matematik.

Subyek populasi penelitian ini adalah siswa kelas VII di satu SMPN di Kabupaten Karawang. Pada penelitian ini diambil dua kelas sebagai sampel dari lima kelas yang ada. Sampel yang digunakan sebanyak 84 siswa dengan rincian 43 siswa di kelompok eksperimen dan 41 siswa di kelompok kontrol. Kelompok eksperimen diajarkan dengan menggunakan pendekatan PMRI, sedangkan kelompok kontrol diajarkan menggunakan pembelajaran konvensional.

Penelitian ini menggunakan desain penelitian pretest dan posttest dengan instrumen penelitian berupa tes kemampuan penalaran matematik dan non tes berupa skala kemandirian belajar matematik. Desain ini terdiri atas dua kelompok yang dipilih secara purposif. Pada awal penelitian dilakukan pretest dan pada akhir penelitian dilakukan posttest. Tes disusun dalam bentuk uraian terdiri dari enam butir soal pada pokok bahasan Segiempat dan Segitiga. Penilaian bukan hanya pada jawaban akhir saja tetapi pada setiap langkah yang ditempuh siswa diberi nilai. Hasil tes siswa akan diolah dengan menggunakan pengujian hipotesis mengenai perbedaan dua rata-rata skor pretest kemudian posttest dan yang terakhir gain ternormalisasi ( $N$-Gain) antara kelompok eksperimen dan kelompok kontrol. Sebelum ditetapkan sebagai instrumen untuk penelitian, soal tes kemampuan penalaran matematik tersebut diujicobakan kepada siswa kelas VIII.

Instrumen non tes pada penelitian ini berupa skala kemandirian belajar matematik yang disusun berdasarkan aspek yang telah ditentukan dalam definisi operasional. Skala ini diberikan kepada kedua kelompok setelah penelitian. Skala kemandirian belajar matematik ini menggunakan skala Likert dengan pilihan jawaban SS (Sangat Sering), S (Sering), KD (Kadang-kadang), JR (Jarang), JS (Jarang Sekali). Skala kemandirian belajar matematik menggunakan pernyataan frekuensi yang berupa kejadian atau perasaan kejadian. Pernyataan yang dibuat bersifat pernyataan positif dan pernyataan negatif. Masing-masing sifat berjumlah 15 pernyataan sehingga total ada 30 pernyataan kemandirian belajar matematik. 


\section{HASIL DAN PEMBAHASAN}

Penelitian ini dilakukan dengan pokok bahasan segiempat dan segitiga selama 12 kali pertemuan. Data hasil penelitian yang dianalisis adalah data pretest dan posttest kemampuan penalaransiswa yang memperoleh pembelajaran dengan pendekatan PMRI maupun pembelajaran secara konvensional.

Sebelum pembelajaran dimulai, guru membagi siswa menjadi beberapa kelompok dengan anggota antara lima atau enam orang yang dipilih secara heterogen. Awal pembelajaran menggunakan pendekatan PMRI, siswa mengalami beberapa kendala. Siswa terbiasa hanya menerima pengajaran dari guru dan langsung mengerjakan latihan soal setelahnya. Siswa belum terbiasa untuk menyelesaikan permasalahan pada soal yang berkaitan dengan konteks pembelajaran atau berkaitan dengan kehidupan seharihari siswa. Sehingga tujuan pembelajaran belum tercapai secara maksimal.

Setiap kelompok akan diberikan masalah dalam bentuk LKS yang telah disediakan oleh guru. Pada kegiatan awal setiap kelompok akan berusaha memahami masalah kontekstual yang diberikan oleh guru dan mencoba menyelesaikannya sendiri. Pada pertemuan selanjutnya, guru berusaha memotivasi siswa untuk bisa memahami konteks dan bisa membuat model-of maupun model-for dari masalah/soal yang telah disediakan oleh guru. Tugas guru selanjutnya adalah berusaha mengarahkan siswa untuk bisa memahami konteks dan menggunakan hasil konstruksi siswa baik model-of maupun model-for untuk menyelesaiakan masalah/soal sesuai tujuan pembelajaran. Keaktifan siswa dalam pembelajaran dengan pendekatan PMRI didukung adanya diskusi dan saling memberikan pendapat dalam menyelesaiakan masalah/soal. Akan tetapi tidak setiap pertemuan menggunakan metode diskusi agar siswa tidak jenuh.

Gambaran umum hasil penelitian tentang kemampuan penalaran matematik dan kemandirian belajar matematik selengkapnya disajikan pada tabel rekapitulasi berikut:

\section{Tabel 1. Rekapitulasi Hasil Pretest dan Posttest Kemampuan Penalaran dan Kemandirian Belajar Matematik}

\begin{tabular}{cccccccccc}
\hline Aspek yang & & \multicolumn{3}{c}{ Pembelajaran PMRI } & \multicolumn{3}{c}{ Pembelajaran Konvensional } \\
\cline { 2 - 9 } diukur & & $n$ & Pretest & Posttest & Gain & $n$ & Pretest & Posttest & Gain \\
\hline Penalaran & $\bar{x}$ & & 4,98 & 14,88 & 0,52 & & 5,05 & 9,37 & 0,23 \\
Matematik & $\%$ & 43 & 20,75 & 62 & - & 41 & 21,04 & 39,04 & - \\
(SMI = 24) & $s$ & & 1,49 & 2,91 & 0,15 & & 1,79 & 1,84 & 0,09 \\
\hline Kemandirian & $\bar{x}$ & & & 90,49 & & & & 86,17 & \\
Belajar & $\%$ & \multirow{2}{*}{43} & - & 60,33 & - & 41 & - & 57,45 & - \\
Matematik & \multirow{2}{*}{$*$} & & & 10,99 & & & & 14,96 & \\
(SMI=150) & & & & & & & & & \\
\hline
\end{tabular}

Keterangan: $\mathrm{SMI}=$ Skor Maksimum Ideal

$\bar{x}>75 \%$ : tinggi; $\quad 60 \% \leq \bar{x} \leq 75 \%$ : sedang; $\quad \bar{x}<60 \%$ : rendah

Berdasarkan Tabel 1 rata-rata pretest kemampuan penalaran matematik siswa kedua kelompok tidak jauh berbeda. Hal ini menunjukkan bahwa kemampuan penalaran matematik awal dari kedua kelompok sampel adalah sama. Sedamgkan rata-rata posttest kemampuan penalaran matematik pada pembelajaran PMRI lebih tinggi daripada pembelajaran konvensional. Pada Tabel 1 terlihat bahwa rata-rata gain pada kemampuan penalaran matematik pembelajaran PMRI juga lebih tinggi daripada 
pembelajaran konvensional. Analisis data kemandirian belajar matematik dimaksudkan untuk melihat kemandirian belajar matematik siswa dalam pembelajaran matematika. Data kemandirian belajar matematik ini diambil hanya skor posttest saja. Adapun pertimbangannya adalah pada dasarnya setiap siswa sudah memiliki sikap kemandirian belajar matematik karena sudah dibimbing dan diarahkan oleh guru ataupun orangtuanya. .

Pengolahan data dilakukan menggunakan analisis uji statistik untuk mengetahui kemampuan awal, pencapaian dan peningkatan kemampuan siswa kelas PMRI maupun kelas konvensional. Untuk mengetahui uji rataan, dilakukan uji normalitas dan uji homogenitas dengan derajat signifikansi 0,05 atau tingkat kepercayaan 95\%. Uji normalitas data menggunakan uji Kolmogorov-Smirnov (KS) dimana pengujian normalitas data tersebut menggunakan software Minitab 16. Apabila data yang diperoleh normal dan homogen dilanjutkan dengan uji-t namun jika data yang digunakan normal tetapi tidak homogen maka dilajutkan dengan uji-t'. Sedangkan apabila data salah satu atau keduanya tidak normal maka pengolahan data menggunakan uji non parametrik.

\section{Tabel 2. Hasil Uji Mann-Whitney Pretest, Posttest, dan Gain Kemampuan Penalaran Matematik}

\begin{tabular}{|c|c|c|c|c|c|c|c|c|}
\hline \multirow{2}{*}{$\begin{array}{c}\text { Kelompok } \\
\text { Sampel } \\
\text { Pembelajaran }\end{array}$} & \multirow[b]{2}{*}{$\mathbf{n}$} & \multicolumn{2}{|c|}{ Pretest } & \multicolumn{2}{|c|}{ Posttest } & \multicolumn{3}{|c|}{ Gain } \\
\hline & & $\begin{array}{c}\text { P- } \\
\text { Value }\end{array}$ & $\begin{array}{l}\text { Inter- } \\
\text { Pretasi }\end{array}$ & $\begin{array}{c}\text { P- } \\
\text { Value }\end{array}$ & $\begin{array}{l}\text { Inter- } \\
\text { pretasi }\end{array}$ & $\begin{array}{c}\bar{x} \\
\text { Gain }\end{array}$ & $\begin{array}{c}\text { P- } \\
\text { Value }\end{array}$ & $\begin{array}{l}\text { Inter- } \\
\text { pretasi }\end{array}$ \\
\hline $\begin{array}{c}P M R I \\
\text { Konvensional }\end{array}$ & $\begin{array}{l}43 \\
41\end{array}$ & 0,8676 & $\begin{array}{c}H_{0} \\
\text { diterima }\end{array}$ & 0,0000 & $\begin{array}{c}H_{0} \\
\text { ditolak }\end{array}$ & $\begin{array}{l}0,52 \\
0,23\end{array}$ & 0,0000 & $\begin{array}{c}H_{0} \\
\text { ditolak }\end{array}$ \\
\hline
\end{tabular}

Keterangan: $\alpha=5 \%$

Berdasarkan hasil uji Mann-Whitney, diperoleh hasil bahwa pada awal pembelajaran tidak terdapat perbedaan pada kemampuan awal penalaran matematik antara pembelajaran PMRI dan konvensional. Dengan demikian, perlu dilakukan pengujian untuk mengetahui pencapaian siswa karena kemampuan penalaran matematik siswa kedua kelompok sama.

Selanjutnya, setelah pembelajaran terdapat pencapaian kemampuan penalaran matematik siswa SMP yang memperoleh pembelajaran dengan pendekatan PMRI lebih baik daripada siswa SMP yang memperoleh pembelajaran dengan cara konvensional pada taraf signifikansi $5 \%$.

Berdasarkan hasil Uji Mann-Whitney pada gain, diperoleh nilai $\mathrm{p}=0,0000$ maka $\mathrm{p}$ $<0,05$ sehingga tolak $H_{0}$. Dapat disimpulkan bahwa peningkatan kemampuan penalaran matematik siswa SMP yang pembelajarannya menggunakan pendekatan PMRI secara signifikan lebih baik daripada pembelarajan yang menggunakan cara konvensional pada taraf signifikansi 5\%. Dari rata-rata gain terlihat bahwa peningkatan kemampuan penalaran matematik yang menggunakan pendekatan PMRI tergolong sedang $(\bar{x}=$ 0,52). Sedangkan peningkatan kemampuan penalaran matematik kelompok pembelajaran secara konvensional tergolong rendah $(\bar{x}=0,23)$.

Berdasarkan pengolahan dan pengujian data diperoleh hasil bahwa kemampuan penalaran matematik kelompok pembelajaran pendekatan PMRI lebih baik daripada kelompok dengan pembelajaran secara konvensional. Pada saat pretest (Tabel 1), ratarata kemampuan awal penalaran matematik pembelajaran PMRI lebih rendah 
dibandingkan pembelajaran konvensional $\left(\bar{x}_{\text {PMRI }} 4,98<\bar{x}_{\text {konvensional }} 5,05\right)$. Setelah diberikan perlakuan rata-rata pembelajaran PMRI menjadi lebih tinggi dibandingkan pembelajaran konvensional yakni $\left(\bar{x}_{\mathrm{PMRI}} 14,88>\bar{x}_{\text {konvensional }} 9,37\right)$.

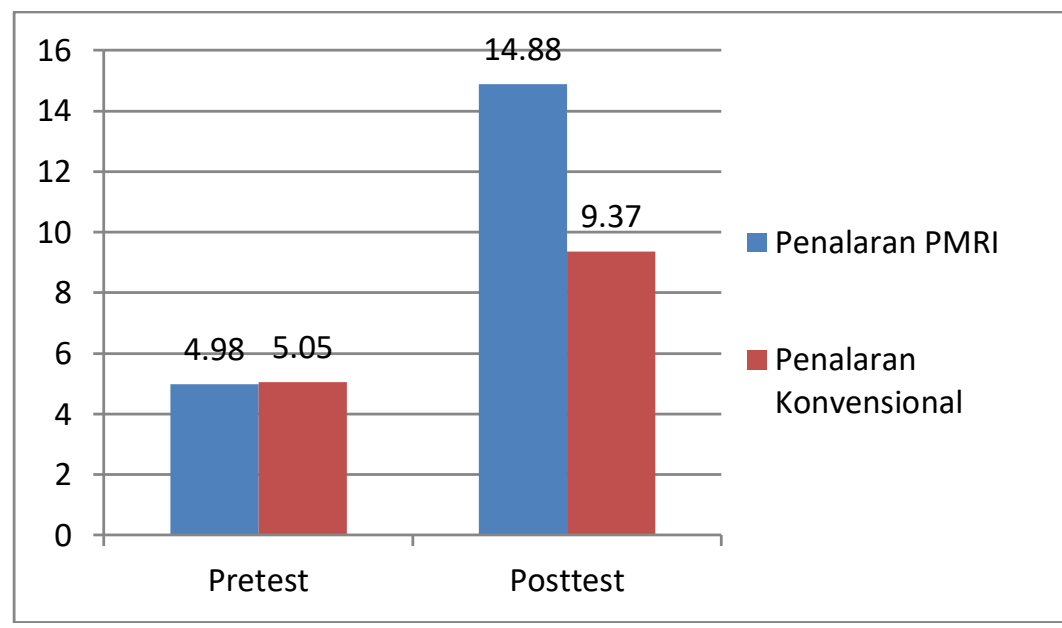

\section{Diagram 1. Rata-Rata Skor Pretest \& Posttest Kemampuan Penalaran Matematik}

Selanjutnya disajikan pengolahan data hasil uji Mann-Whitney kemandirian belajar matematik.

Tabel 3
Hasil Uji Mann-Whitney Skala Kemandirian Belajar Matematik
\begin{tabular}{|llll}
\hline Kelompok Sampel & n & P-Value & Interpretasi \\
\hline Realistic Mathematics Education & 43 & 0,0241 & \multirow{2}{*}{$H_{0}$ ditolak } \\
Konvensional & 41 & & \\
\hline
\end{tabular}

Berdasarkan hasil uji Mann-Whitney tersebut diperoleh nilai $\mathrm{p}=0,0241$ sehingga $\mathrm{p}<0,05$ maka $\mathrm{H}_{0}$ ditolak. Dengan demikian, dapat disimpulkan bahwa kemandirian belajar matematik antara siswa SMP yang memperoleh pembelajaran dengan pendekatan PMRI lebih baik daripada siswa yang memperoleh pembelajaran dengan cara konvensional pada taraf signifikansi $5 \%$.

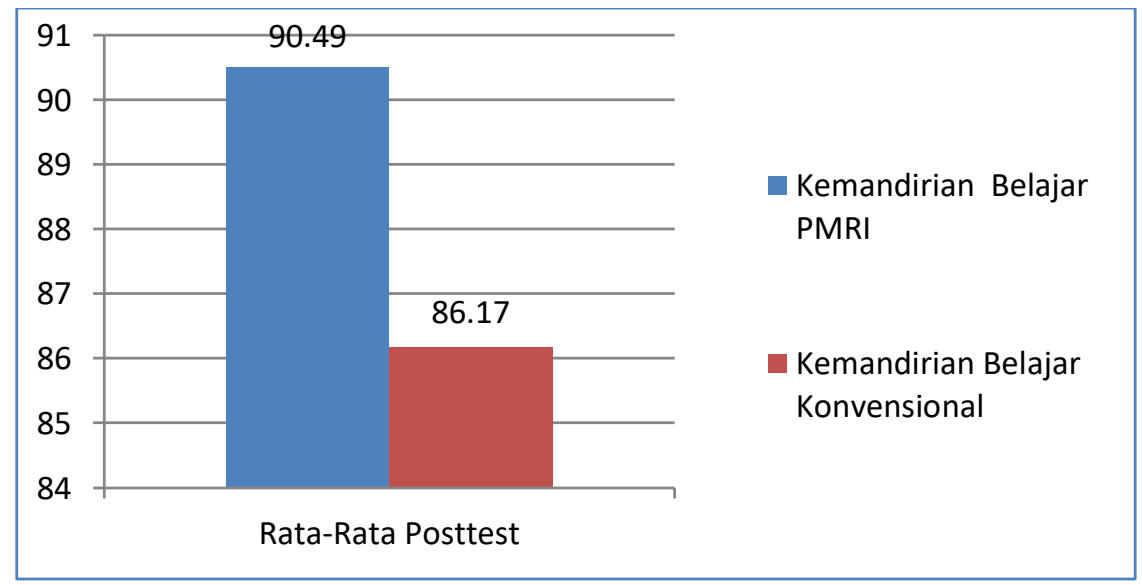

Diagram 2. Rata-Rata Posttest Kemandirian Belajar Matematik 


\section{SIMPULAN DAN SARAN}

Berdasarkan hasil penelitian dan pembahasan yang telah dikemukakan dapat disimpulkan bahwa pencapaian dan peningkatan kemampuan penalaran matematik siswa yang memperoleh pembelajaran dengan pendekatan PMRI lebih baik daripada siswa yang memperoleh pembelajaran secara konvensional. Peningkatan kemampuan penalaran matematik yang menggunakan pendekatan PMRI tergolong sedang. Sedangkan peningkatan kemampuan penalaran matematik yang menggunakan pembelajaran konvensional tergolong rendah. Kemanidirian belajar matematik siswa yang memperoleh pembelajaran melalui pendekatan PMRI lebih baik daripada siswa yang memperoleh pembelajaran secara konvensional.Terdapat asosiasi cukup antara kemampuan penalaran dan kemandirian belajar matematik siswa yang pembelajarannya menggunakan pendekatan PMRI

Agar hasil yang diperoleh lebih baik maka guru harus terus mengawasi jalannya proses pembelajaran untuk memastikan agar tujuan pembelajaran dapat tercapai. Dalam PMRI ada tahap penggunaan konteks dan penggunaan hasil konstruksi/produksi siswa sehingga siswa memahami masalah dan membuat pondasi cara berpikir untuk menyelesaikan masalah baru. Selain itu alokasi waktu untuk diskusi sebaiknya diperhatikan. Berdasarkan penelitian, siswa mengalami kesulitan pada awal pembelajaran, namun dapat menyesuaikan pada pertemuan-pertemuan berikutnya dan mampu menjalankan karakteristik PMRI dalam proses pembelajaran. Kesulitan siswa tersebut saat menyelesaikan soal kemampuan penalaran matematik dengan indikator menghubungkan benda nyata, gambar atau diagram ke dalam ide matematika.

\section{UCAPAN TERIMA KASIH}

Penulis mengucapkan terimakasih kepada Dr. Sungkono, SE., MM. selaku Ketua Lembaga Penelitian dan Pengabdian pada Masyarakat Universitas Buana Perjuangan Karawang yang telah memberi arahan sehingga penelitian dapat selesai dengan baik, dan semua pihak yang telah membantu sehingga jurnal ini dapat tersusun.

\section{DAFTAR PUSTAKA}

Bakker, A. 2004. Design Research in Statistics Education: On Symbolizing and Computer Tools. Utrecht, the Netherlands: CD- $\beta$ Press. p6.

Bezold, Angela \& Silke Ladel. 2013. Reasoning In Primary Mathematics - An ICTSupported Environment. "WG 13 Papers CERME8 Manavgat-Side, Antalya Turkey". p2-6.

Brenner, Mary E. 1998. Development of Mathematical Communication in Problem Solving Groups By Language Minority Students Bilingual Research Journal, 22:2, $3, \& 4, \mathrm{p} 109-128$. 
Kwon, Oh Nam. Conceptualizing The Realistic Mathematics Education Approach In The Teaching And Learning Of Ordinary Differential Equations. Seoul, Korea: Ewha Womans University, Department Of Mathematics Education.

NCTM. 2000. Principles and Standards for School Mathematics. Reston: NCTM

Noornia, A. 2008. Pengembangan Pendidikan Matematika Realistik. Makalah yang disajikan pada kegiatan KOMSOF Mahasiswa Jurusan Matematika FMIPA UNJ . p12

Nunes, Terezinha. et.al. 2009. Development of Maths Capabilities and Confidence in Primary School. Research Report DCSF-RR118 University of Oxford. p3.

Panhuizen, Marja van den Heuvel. (2000). Mathematics education in the Netherlands: A guided tour. Utrecht, the Netherlands: Utrecht University. p3-4 [ON LINE] Tersedia: http://www.fi.uu.nl/en/rme/ TOURdef+ref.pdf

Shadiq, Fadjar. 2004. Penalaran, Pemecahan Masalah dan Komunikasi dalam Pembelajaran Matematika. Diklat Instruktur/Pengembangan Matematika SMP Jenjang Dasar. Yogyakarta: PPPG Matematika.Tgl 10-23 Oktober 2004.

Shanty, N. Octavarulia. 2011. Design Research On Mathematics Education: Investigating The Progress Of Indonesian Fifth Grade Students" Learning On Multiplication Of Fractions With Natural Numbers. Indonesian Mathematical Society-Journal on Mathematics Education (IndoMS-JME). p152-153

Sumarmo, U. 2013. Kumpulan makalah Berpikir dan disposisi matematik serta pembelajarannya. FMIPA UPI. Bandung.

Tandililing, E. 2011. Peningkatan Komunikasi Matematik Serta Kemandiran Belajar Siswa SMA Melalui Strategi PQ4R Disertai Bacaan Refutation Text. Jurnal Pendidikan Matematika dan IPA. Vol. 2 No. 1. p12

Wijaya, Ariyadi. 2008. Design Research in Mathematics Education: Indonesian Traditional Games as Means to Support Second Graders' Learning of Linear Measurement. Utrecht, the Netherlands: Utrecht University.

Wijaya, Ariyadi. 2012. Pendidikan Matematika Realistik Suatu Alternatif Pendekatan Pembelajaran Matematika. Yogyakarta: Graha Ilmu 